\title{
PENERAPAN REGRESI POISSON GENERALIZED POISSON REGRESSION DALAM MEMODELKAN KASUS ANGKA KEMATIAN IBU DI SUMATERA BARAT TAHUN 2015
}

\author{
NADIAH RAMADHANI, FERRA YANUAR, HAZMIRA YOZZA \\ Jurusan Matematika, \\ Fakultas Matematika dan Ilmu Pengetahuan Alam, Universitas Andalas, \\ Kampus UNAND Limau Manis Padang, Indonesia \\ email : nadiahramadhani94@gmail.com
}

\begin{abstract}
Dalam analisis regresi Poisson, variabel respon harus memnuhi asumsi yaitu ragam sama dengan rata-rata. Namun, dalam analisisnya hal yang kadang terjadi adalah ragam dari variabel respon lebih besar dari nilai rata-rata yang disebut terjadinya kasus overdispersi. Penelitian ini menjelaskan tentang penanganan untuk model regresi Poisson yang mengalami kasus overdispersi. Model yang digunakan adalah Generalized Poisson Regression. Tujuan dari penelitian ini adalah untuk memilih model terbaik yang digunakan untuk memodelkan kasus angka kematian ibu di Sumatera Barat Tahun 2015. Data yang digunakan adalah data sekunder yang diperoleh dari Dinas Kesehatan Sumatera Barat. Hasil analisis menunjukkan bahwa model Generalized Poisson Regression yang terbaik digunakan untuk mengatasi kasus overdispersi pada model regresi Poisson.

Kata Kunci: Overdispersi, Generalized Poisson Regression, regresi Poisson
\end{abstract}

\section{PENDAHULUAN}

Analisis regresi adalah salah satu metode yang digunakan untuk menganalisia hubungan antara variabel respon dan variabel prediktor. Pada umumnya, metode analisis regresi digunakan untuk menganalisis data variabel responnya berjenis kontinu, namun dalam beberapa aplikasinya data variabel respon yang akan dianalisis dapat berupa data cacah. Salah satu model regresi yang dapat digunakan untuk menganalisis hubungan antara variabel respon diskrit yang berupa data cacah dengan variabel prediktor berupa data diskrit, kontinu, kategorik atau campuran adalah model regresi Poisson. Dalam model regresi Poisson, karakteristik yang penting adalah rata-rata harus sama dengan ragam atau disebut equidispersi. Namun pada praktiknya sering ditemui data diskrit dengan ragam lebih besar dibanding rata-rata. Kondisi ini disebut dengan overdispersi.

\section{LANDASAN TEORI}

\subsection{Regresi Poisson}

Regresi Poisson termasuk ke dalam Generalized Linier Model dan merupakan salah satu bentuk regresi yang digunakan untuk model data cacahan. Variabel respon 
dalam regresi Poisson berasal dari data cacahan yang menyebar mengikuti distribusi Poisson. Jika variabel respon $Y$ merupakan data diskrit yang berdistribusi Poisson dengan parameter $\mu$, maka fungsi kepekatan peluangnya adalah [1]

$$
f(y ; \mu)=\frac{\exp (-\mu) \cdot \mu^{y}}{y !}, y=0,1,2, \cdots
$$

Pada model regresi Poisson, biasanya fungsi penghubung yang digunakan adalah fungsi logarithma natural (ln) [2], yang menjamin bahwa nilai variabel yang diharapkan dari variabel responnya akan bernilai nonnegatif. Berikut model regresi Poisson dengan menggunakan fungsi penghubung.

$$
g\left(\mu_{i}\right)=\ln \left(\mu_{i}\right)=\exp \left(\beta_{0}+\beta_{1} x_{1 i}+\beta_{2} x_{2 i}+\cdots+\beta_{p} x_{p i}\right) .
$$

\subsection{Overdispersi}

Model regresi Poisson mensyaratkan equidispersi, yaitu kondisi dimana nilai ratarata dan ragam dari variabel respon bernilai sama. Namun, adakalanya terjadi overdispersi dalam data yang dimodelkan dengan distribusi Poisson. Overdispersi adalah kondisi pada saat ragam lebih besar dari nilai rata-rata. Hal ini mengindikasikan bahwa model regresi Poisson tidak cocok untuk data yang mengandung kasus overdispersi. Overdispersi terjadi apabila rasio antara ragam dan nilai rata-rata lebih dari $2.5[5]$.

\subsection{Generalized Poisson Regression}

Model Generalized Poisson Regression merupakan suatu model regresi yang digunakan untuk menganalisis hubungan antara sebuah variabel respon yang berupa data cacahan dengan satu atau lebih variabel prediktor. Generalized Poisson Regression dapat digunakan baik dalam keadaan underdispersi, equidispersi dan overdispersi. Fungsi kepekatan peluangnya adalah [3]

$$
f\left(y_{i}, \mu_{i}, \alpha\right)=\left(\frac{\mu_{i}}{1+\alpha \mu_{i}}\right)^{y i} \frac{\left(1+\alpha \mu_{i}\right)^{y} i-1}{y_{i} !} \exp \frac{\left(-\mu_{i}\left(1+\alpha y_{i}\right)\right)}{1+\alpha \mu_{i}}, y_{i}=0,1,2, \cdots
$$

dengan $\alpha$ merupakan parameter dispersi,

\subsection{Multikolinieritas}

Multikolinieritas adalah terjadinya hubungan linier antara variabel prediktor dalam suatu model regresi linier berganda. Untuk mendeteksi adanya multikolinieritas dalam model regresi linier berganda dapat digunaka nilai Variance Inflation Factor (VIF). Rumus VIF dapat ditulis sebagai berikut.

$$
V I F=\frac{1}{1-R^{2}}
$$


114 Nadiah Ramadhani dkk.

\subsection{Pengujian Signifikansi Parameter Model}

\subsubsection{Uji Simultan}

Pengujian signifikansi secara simultan untuk estimasi parameter model regresi Poisson dan Generalized Poisson Regression menggunakan uji rasio likelihood dengan hipotesis sebagai berikut.

$$
\begin{aligned}
& H_{0}: \beta_{0}=\beta_{1}=\cdots=\beta_{p}=0 \\
& H_{1}: \text { Terdapat setidaknya salah satu } \beta_{k} \neq 0 ; k=0,1,2, \cdots, p .
\end{aligned}
$$

Statistik uji yang digunakan adalah:

$$
G=-2 \ln \left(l_{0}-l_{1}\right)
$$

dimana $l_{1}$ adalah nilai log-likelihood untuk model yang mengandung seluruh variabel prediktor dan $l_{0}$ adalah log-likelihood untuk model yang tidak mengandung variabel prediktor. Tolak $H_{0}$ jika statistik uji $G>X_{(\alpha, n-k-1)}^{2}$.

\subsubsection{Uji Parsial}

Pengujian parameter model untuk mengetahui pengaruh yang dihasilkan oleh variabel prediktor terhadap variabel respon secara parsial. Statistik uji yang digunakan untuk uji parsial adalah uji Wald. Hipotesis yang digunakan adalah sebagai berikut.

$$
\begin{aligned}
& H_{0}: \beta_{j}=0 \\
& H_{1}: \beta_{j} \neq 0 ; j=1,2, \cdots, p .
\end{aligned}
$$

Statistik uji yang digunakan adalah:

$$
W_{j}=\left(\frac{\hat{\beta_{1}}}{\operatorname{se}\left(\hat{\beta_{1}}\right)}\right)^{2}
$$

Kriteria pengujian adalah tolak $H_{0}$ jika $W_{j}>X_{(\alpha, 1)}^{2}$. Penolakan $H_{0}$ pada tingkat signifikansi $\alpha$ berarti bahwa variabel prediktor ke-j tertentu memiliki kontribusi yang signifikan terhadap variabel respon $\mathrm{Y}$.

\subsection{Uji Kolmogorov-Smirnov}

Suatu uji kebaikan model yang menguji tingkat kesesuaian antara distribusi serangkaian nilai sampel (skor yang diobservasi) dengan suatu distribusi teoritis tertentu adalah uji Kolmogorov-Smirnov. Hipotesis uji Kolmogorov-Smirnov adalah:

$$
\begin{aligned}
& H_{0} \text { : Data mengikuti distribusi tertentu, } \\
& H_{1} \text { : Data tidak mengikuti distribusi tertentu. }
\end{aligned}
$$

Statistik uji yang digunakan adalah [4]:

$$
D=\max \left|F_{o}(x)-S_{N}(x)\right|
$$


Kriteria untuk pengujian ini adalah tolak $H_{0}$ jika nilai $D_{\text {hitung }}$ lebih besar dari nilai $D_{\text {tabel }}$. Jika $\alpha=0,05$ dengan banyak pengamatan $\mathrm{N}$ maka $D_{\text {tabel }}$ sebagai berikut $[4]$.

$$
D_{\text {tabel }}=\frac{1,36}{\sqrt{N}}
$$

\subsection{Pemilihan Model Terbaik}

Pemilihan model terbaik dari beberapa kemungkinan model Generalized Poisson Regression menggunakan nilai AIC (Akaike's Information Criterion). Akaike's Information Criterion diperkenalkan pada tahun 1973 oleh Akaike sebagai pendekatan penaksir yang tak bias dari suatu hasil pemodelan. AIC digunakan untuk melihat kecocokan model terhadap data. Nilai AIC dapat dinotasikan sebagai berikut [2].

$$
A I C=-2 \ln L(\beta)+2 k .
$$

Menurut [2] model regresi terbaik adalah model regresi yang memiliki nilai AIC terkecil.

\subsection{Angka Kematian Ibu}

Kematian ibu adalah kematian wanita dalam masa kehamilan, persalinan dan dalam masa 42 hari (6 minggu) setelah berakhirnya kehamilan tanpa memandang usia kehamilan maupun tempat melekatnya janin, oleh sebab apa pun yang berkaitan dengan atau diperberat oleh kehamilan atau pengelolaannya, bukan akibat kecelakaan.

\section{Metode Penelitian}

Variabel data yang digunakan dalam penulisan ini angka kematian ibu di Sumatera Barat yang dikelompokkan per kabupaten/kota sebagai variabel respon (Y) dan variabel prediktor $(\mathrm{X})$ meliputi:

(1) Ibu hamil melaksanakan program K1 (X1) dalam persentase

(2) Ibu hamil melaksanakan program K4 (X2) dalam persentase

(3) Ibu nifas yang mendapatkan vitamin A (X3) dalam persentase

(4) Persalinan ditolong oleh tenaga kesehatan (X4) dalam persentase

(5) Ibu hamil yang mendapatkan Fe1 (X5) dalam persentase

(6) Ibu hamil yang mendapatkan Fe3 (X6) dalam persentase

(7) Kehamilan beresiko tinggi (X7) dalam persentase

(8) Rumah tangga ber-PHBS (Perilaku Hidup Bersih dan Sehat) (X8) dalam persentase

Langkah langkah analisis data yang dilakukan dalam penelitian ini adalah sebagai berikut:

(1) Melakukan uji Kolmogorov-Smirnov untuk menguji apakah variabel respon $Y$ mengikuti distribusi Poisson atau tidak 
116 Nadiah Ramadhani dkk.

(2) Mendeteksi adanya multikolinieritas

(3) Menentukan model regresi Poisson

(4) Menghitung nilai koefisien overdispersi untuk mengidentifikasi kejadian overdispersi

(5) Jika terjadi overdispersi, kemudian dilanjutkan dengan estimasi variabel Generalized Poisson Regression

(6) Menentukan model Generalized Poisson Regression

(7) Melakukan pengujian kesesuaian Generalized Poisson Regression

(8) Menentukan model terbaik

\section{Hasil dan Pembahasan}

Setelah diketahui bahwa angka kematian ibu berdistribusi Poisson, selanjutnya akan dilakukan pengujian overdispersi. Pengujian overdispersi dapat dilakukan dengan memperhatikan nilai rata-rata dengan ragam Dapat dihitung bahwa rasio dari ratarata dengan ragam adalah 3.5999. Karena rasio antara rata-rata dengan ragam angka kematian ibu lebih dari 2.5 maka dapat disimpulkan bahwa pada data angka kematian ibu telah terjadi overdispersi. Untuk mengatasi hal tersebut, maka dilakukan pemodelan menggunakan Generalized Poisson Regression.

Model Generalized Poisson Regression yang diperoleh dari data yang dianalisis adalah:

$$
\hat{\mu}=\exp \left(5.015-0.057 x_{2}-0.0201 x_{5}+0.0416 x_{6}\right) .
$$

Interpretasi dari model dengan dugaan tersebut adalah rata-rata angka kematian ibu di Sumatera Barat tahun 2015 cenderung turun menjadi 0.944 kali jika persentase ibu hamil yang melaksanakan program K4 naik 1\% dengan asumsi variabel prediktor lain konstan. Rata-rata angka kematian ibu di Sumatera Barat tahun 2015 cenderung turun menjadi 0.980 kali jika persentase ibu hamil yang mendapatkan tablet Fe1 naik 1\% dengan asumsi variabel prediktor lain konstan. Rata-rata angka kematian ibu di Sumatera Barat tahun 2015 cenderung naik menjadi 1.041 kali jika persentase ibu hamil yang mendapatkan tablet Fe3 naik 1\% dengan asumsi variabel prediktor lain konstan. Hal ini tidak sesuai yang diharapkan, yaitu seharusya mendapatkan tablet Fe3 mampu menurunkan rata-rata angka kematian ibu, namun hasil pemodelan menunjukkan hal yang sebaliknya.

Pemilihan model terbaik dilakukan antara model regresi Poisson dengan model Generalized Poisson Regression. Perbandingan kedua model disajikan pada Tabel 1. Berdasarkan Tabel 2 dapat dilihat bahwa kriteria model terbaik yang memiliki nilai

Tabel 1. Uji Model Terbaik

\begin{tabular}{|c|c|c|}
\hline Kriteria & Regresi Poisson & Generalized Poisson Regression \\
\hline AIC & 100.943 & -1.852 \\
\hline Log-Likelihood & -46.471 & 50.72 \\
\hline
\end{tabular}


AIC, yang lebih kecil dan nilai Log-Likelihood yang lebih besar adalah Generalized Poisson Regression. Namun untuk lebih mempertegas berikut disajikan Tabel nilai Standard Error.

Tabel 2. Uji Model Terbaik

\begin{tabular}{|c|c|c|}
\hline Kriteria & $\begin{array}{c}\text { Standard Error } \\
\text { Regresi Poisson }\end{array}$ & $\begin{array}{c}\text { Standard Error } \\
\text { Generalized Poisson Regression }\end{array}$ \\
\hline Intersep & 1.105 & 1.532 \\
\hline Ibu hamil melaksanakan K4 $\left(X_{2}\right)$ & 0.014 & 0.019 \\
\hline Ibu hamil melaksanakan Fe1 $\left(X_{5}\right)$ & 0.005 & 0.007 \\
\hline Ibu hamil melaksanakan Fe3 $\left(X_{6}\right)$ & 0.009 & 0.012 \\
\hline
\end{tabular}

Berdasarkan nilai Standard Error yang disajikan pada Tabel 2 dapat dilihat bahwa nilai Standard Error yang terjadi pada Generalized Poisson Regression mengalami peningkatan. Sehingga model Generalized Poisson Regression lebih baik dari pada model regresi Poisson.

\section{KESIMPULAN}

Dari pembahasan diperoleh model terbaik untuk angka kematian ibu di Sumatera Barat tahun 2015 adalah model yang dihasilkan dengan menggunakan model Generalized Poisson Regression, yaitu

$$
\hat{\mu}=\exp \left(5.015-0.057 x_{2}-0.0201 x_{5}+0.0416 x_{6}\right) .
$$

\section{UCAPAN TERIMA KASIH}

Ucapan terima kasih disampaikan kepada Riri Lestari, M.Si, Dr. Arrival Rince Putri, Dr. Maiyastri yang telah membantu merevisi dan penyempurnaan karya tulis ini.

\section{Daftar Pustaka}

[1] Bain, L.J and M. Engelhardt. 1991. Introduction to Probability and Mathematical Statistics Second Edition. Duxbury Press, California.

[2] Hilbe, Joseph M. 2001. Negative Binomial Regression. Second Edition. Cambridge University Press., New York

[3] Ismail, N and A.A. Jemain. 2007. Handling Overdispersion with Negative Binomial and Generalized Poisson Regression Model. Casualty Actuarial Society Forum, Malaysia.

[4] Wingkelman, R. 2008. Econometric Analysis of Count Data 5th. Springer, Berlin.

[5] Yulianingsih, S.A, K.G Sukara dan L.P Suciptawati. 2012. Penerapan Regresi Poisson untuk mengetahui Faktor-Faktor yang mempengaruhi Jumlah Siswa/SMK yang tidak lulus di Bali. E-Jurnal Matematika.1. 59 - 63 